American Journal of Economics and Business Administration 3 (2): 410-415, 2011

ISSN 1945-5488

(C) 2011 Science Publications

\title{
Tax Exportability in Tourism Market
}

\author{
${ }^{1}$ Mohammad Mohebi, ${ }^{2}$ Khalid Abdul Rahim, \\ ${ }^{3}$ Lee Chin and ${ }^{4}$ Khairil Wahidin Awang \\ ${ }^{1}$ Department of Business Management, Faculty of Management, \\ Hormozgan University, Bandarabbas, Iran \\ ${ }^{2}$ Institute of Agricultural and Food Policy Studies, \\ ${ }^{3}$ Department of Economics, Faculty of Economics and Management, \\ ${ }^{4}$ Department of Hospitality and Recreation, Faculty of Economics and Management, \\ University Putra Malaysia, Malaysia
}

\begin{abstract}
Problem statement: Tax incidence is a basic topic in public economics as the tourism industry is an increasingly major contributor to government revenue. Generally, government taxation objectives are for the purpose of financing programs that improve people's lives and economic prosperity, accelerate economic growth and allow for access to sustainable development. In the first view, tax policy decisions by government are based on their effects on the distribution of economic welfare. Therefore, to provide incentives for governments to select a suitable tax policy, exportability of tax is important. Hotel room tax is one of the main parts of tourism tax. Despite the importance of tax for government, it seems that the exportability of hotel room tax is still not well known. Therefore, understanding the counteraction of foreign visitors with respect to its main factors is important for the Malaysian government and tourism management. To achieve these aims, this study examines tax incidence effects on the tourism market. Approach: We use hotel room as representative of tourism market. Quarterly data from 1995-2009 are used and a dynamic model of simultaneous equation is employed. Results: Our results indicate that in the short run supply is elastic and demand is inelastic.But in the long run both demand and supply are elastic to price. Conclusion: Based the results if the government imposes one ringgit (Malaysian currency) tax on hotel room price, the tourist contribution is more than 89 and $74 \%$ in the short run and long run respectively. Hence, we conclude that the Malaysian tourism market is exportable. Our results also indicate that tax on hotel has no negative social effects in the short run.
\end{abstract}

Key words: Tourism demand, hotel room tax, tax exportability, dynamic model, simultaneous equations, Malaysian currency, economic prosperity, tourism market, Weighted TwoStage Least Squares (W2SLS), occupancy rate

\section{INTRODUCTION}

The Malaysian government has expanded the tourism industry and set several development targets after 1970, for instance, creating more employment opportunities, increasing foreign exchange earnings and income levels, nurturing local development, strengthening and spreading the economic foundation and improving government revenue. Malaysian tourism industry has been growing considerably in recent years. The number of tourist's arrivals had a growth rate of 25\% during 2006-2008. In the same period, the rate was $4 \%$ for Singapore and Thailand. In comparison, although during this period Malaysia had a greater number of tourist's arrivals but earned income less than Thailand and Singapore (Mohebi and Khalid, 2010).

Basically, tourism revenue can be divided into two parts, namely: private and public revenue. Tourism expenditure is a source of private revenue, while public returns from tourism come from tax on tourism goods and services. With the increase in the public sector needs to finance the projects and activities, there will be increased importance of tax incidence. While taxation increases the government revenue, it also affects the distribution of economic welfare, and even changes the distribution of economic resources (Mohebi and Khalid, 2010).

Corresponding Author: Mohammad Mohebi, Department of Business Management, Faculty of Management, Hormozgan University, Bandarabbas, Iran 
It should be noted that taxes on tourism have a negative impact on tourism flow. Today, tax incidence is a basic topic in public economics as the tourism industry is an increasingly major contributor to government revenue. Generally, government taxation objectives are for the purpose of financing programs that improve people's lives and economic prosperity, accelerate economic growth and allow for access to sustainable development. In the first view, tax policy decisions by government are based on their effects on the distribution of economic welfare. Countries have very different philosophies about taxation and very different methods of collecting their revenue (Anastassiou and Dritsaki, 2005). Therefore, to provide incentives for governments to select a suitable tax policy, exportability of tax is important. Hotel room tax is one of the main parts of tourism tax. Despite the importance of tax for government, it seems that the exportability of hotel room tax is still not well known.

The purpose of this study is examining the tax exportability in Malaysian tourism market. Therefore a system of supply and demand model is estimated using the Weighted Two-Stage Least Squares (W2SLS) estimator. The data set includes quarterly time series from 1995q1 to 2009q4 (60 observations).

Tourism market model: An important question arises now: what is tourism? In fact, it sometimes seems to have too many answers. Tourism researchers and associations, governmental agencies and individual businesses have presented various definitions indicating their own standpoints and interests. Some researchers have, however, looked at "tourism" as being synonymous with the actions and influences of tourists. The others have applied the term to imply a course of study and body of research. Basically the tourism definitions can be categorized based on their clear content into three categories: "technical", "economic", and "holistic" Berno (2001).

According to smith "Tourism is the aggregate of all businesses that directly provide goods or services to facilitate business, pleasure and leisure activities away From the home environment” (Smith, 1988).

Smith divided travel commodities into two distinct groups or "tiers". He alleges that the first group of goods is essentially "pure tourism".

On the other side are the commodities of the second group, namely "mixed" commodities, which are supplied by businesses akin to restaurants, which serve both residents and travellers. Businesses supplying commodities within the first group, such as airlines, would vanish if there is existed no travel. On the contrary, businesses within the second group would survive if there were no travel, albeit at a markedly reduced level. Studies on the supply of tourism services, whether theoretical or empirical, are rare in the literature Seifolddini-Faranak et al. (2009). Most empirical researches on tourism deem supply quite elastic. Some studies have revealed that not always true to assume the infinite elasticity of supply. For instance, Fuji and Mak (1981) estimated the supply elasticity of Hawaii lodging services at nearly 2 and believed that large fluctuations in hotel room prices are not unusual.

There are less methodized studies conducted from a supply side standpoint than those on (forecasting) demand for tourism, including tourism services. According to Smith (1988), among the reasons for this are intricacy and heterogeneity of tourism as a product or goods which are restricted, but not completely banned, the use of standard microeconomic models applied to the tourism industry, and also employment of production, cost and supply functions. This fact can be deduced from the contributions of Arbel and Ravid (1983); Fujii and Mak (1981); Mak (1988) and Hiemstra and Ismail (1993) who concentrated, to some extent, on the way supply of hotel rooms is affected by variations in the level of costs borne by hotels.

Rising from $32.0 \%$ in 1995 to $32.8 \%$ in 2000 , accommodation was the largest portion of the tourist expenditure pattern in Malaysia. Increasing from 21.0$23.1 \%$ during the same period, shopping expenditure continued to be the second biggest portion of tourist expenditure. This follows the efforts to promote Malaysia as a shopping paradise (8th Malaysia Plan period report).

The lodging sector is distinguished by its variety. In fact, not only does there is exist an extensive variety of accommodation sorts for tourists, but there are also factors like the location, ownership, and diverse cost structures that cause a variety of supply reactions to market circumstances. Most hotels and motels have a fixed supply of rooms available for letting, and to be profitable, there must be volume or revenue maximization, through selling capacity, the goal being to achieve 100 percent occupancy rate. In this way, it is like airlines. Modeling tourism supply, due to the complex interrelationships between the tourism phenomenon and exogenous social, economic and environmental issues are difficult. Efforts to characterize tourism market supply have been restricted due to a general lack of product definition and explicit incorporation of external characteristics critical to producing tourism output. On the other word, there is a problem in tourism supply measurement because there are no precise and determined criteria of tourism supply. Therefore, we cannot say exactly that the means of tourism supply is services related to tourism or goods supply is tourism. Hence, we have to ignore studies relating to tourism supply or place minimum emphasis on them. Near to all of researchers use supplies of hotel 
room as tourism supply in their researches. It seems that the hotel room is the best selection in our hand as used before by Zhou et al. (2007). In this study we focused on a group of commodities that called pure tourism. But we are limited to select only one part of pure tourism as accommodation. The share of accommodation in tourism expenditure is over the $33 \%$ of total tourism expenditure. Indeed with using accommodation sector as tourism industry we only will be cover one third for tourism industry. On the other hand, generally the goods that tourists use usually have substitutes or supplementary features. Hotels, restaurants, and transportation in general are complementary and also, the kinds of hotel or restaurant used by tourists can be interchangeable. A hotel room in tourism is not substitute but also complementary goods. Considering that a hotel room for tourists is complementary goods, hotel room prices can affect tourists' decision in the selection of a certain destination. In this respect, in determining tourism behavior, changes in price using hotel room as a proxy for tourism goods is acceptable. Likewise, tourists' response to taxes relating to hotel costs could be generalized to other costs. This assumption is however not acceptable in the case when goods have the ability to substitute for the tourist.

One approach to modeling tourism supply is to estimate an inverted tourism supply curve. In this approach the supply price of hotel rooms is assumed to be a mark-up over marginal cost. This approach before was used by Zhou et al. (2007). The supply function can be obtained from the profit maximization rule; we suppose that the production functions can be presented by:

$\mathrm{Q}=\mathrm{AL}^{\alpha} \mathrm{k}^{\gamma} \mathrm{z}^{\beta}$

The terms of Iso cost line is:

$C=P L . L+P K \cdot K+P Z \cdot Z$

Where:

$\mathrm{Q}=$ The total quantity of rented rooms

$\mathrm{PL}=$ The input prices of labor

$\mathrm{PK}=$ The input prices of capital

$\mathrm{PZ}=$ Prices of other inputs

Then we obtain the marginal cost function:

$$
\begin{aligned}
& \mathrm{MC}=\mathrm{Q}^{\frac{1}{\alpha+\beta+\gamma}-1} \mathrm{~T}^{\frac{1}{\alpha+\beta+\gamma}} \mathrm{PL}^{\frac{\alpha}{\alpha+\beta+\gamma}} \\
& \mathrm{PK}^{\frac{\gamma}{\alpha+\beta+\gamma}} \mathrm{PZ}^{\frac{\beta}{\alpha+\beta+\gamma}}
\end{aligned}
$$

Since marginal cost is homogeneous of degree one in the input prices.
We can write the above equation as:

$M C=f\left(Q, \frac{P L}{P K}, \frac{P Z}{P K}\right)$

MC can be specified as:

$M C=f(Q, P L, P K, P Z)=P M$

where, $\mathrm{MC}=$ Marginal Cost.

As mentioned, in this study the supply price of hotel rooms is assumed as a mark-up over marginal cost:

$\mathrm{pm}=\mathrm{l}(\mathrm{Q}, \mathrm{P}, \mathrm{Z})$

Where:

$\mathrm{Pm}=$ Price variable

$\mathrm{Q}=$ The total rooms rented

$\mathrm{P}=$ Measures the overall production cost

Therefore, the supply model for tourism in Malaysia is:

A R R $=F($ Q R D, O C P, P P M, Z S )

where, OCP is the room occupancy rate, defined as the ratio of quantity demand of rooms to room supply or room capacity as it used before by Qu et al. (2002) in Hong Kong tourism model, ARR is average daily hotel room rate (price variable), PPM is producer price index (measures the overall production cost) QRD is total room rented and $\mathrm{ZS}$ is other factors.In demand side we used the classical tourism demand model. According to the classical economic theory, the important determinants of the demand for foreign tourism include: The price of tourist goods and services with respect to those of pertinent substitutes; the tourists' incomes and other factors which may alter travelers' preferences for tourism.

Tourists are also responsive to form of transportation costs (airfares) and living costs (residence, food) at the destination country. This variable is normally deleted from the demand model since data from the past on airfares are not easily available. According to Fosu and Magnus (2008) income is one of the major independent variables in a model of tourism demand. According to the economic theory the relationship between quantity of demand and income can be either positive or negative. For the normal good the relationship between two variables is positive and for inferior goods is negative. An increase in real per capita income in the origin countries will 
increase the number of people visiting a certain destination holding all other factors constant.

In terms of price effects, Crouch (1994) claims that "economic theory confirms that price must be included in any demand study, but in the study of tourism, the issue of price is particularly vexatious". Price comprises the price of services for which is quite enough no single price index. In fact, price consists of the price of reaching a destination which includes also an opportunity cost for travel time (Yet some receive enjoyment from the travel itself.), the cost of local goods and services modified to allow for the exchange rate. Furthermore, some trips have multiple destinations. Aside from these intricacies, theory states that the actual exchange rate should be an influential factor in the demand for international travel. Several studies, however, separated the nominal exchange rate effects from the local price effects. The necessity for incorporation of variables standing for tourism prices raises a big challenge to empirical tourism researchers. The problem originates from the fact that indices for tourism prices are often inaccessible to researchers. In view of this fact, researchers have employed exchange rate variables to stand for tourism prices. Either relative nominal or real exchange rates which resemble nominal exchange rates but modified due to inflation in both origin and destination countries are used to represent the relative prices. The common idea in both methods is that the indices are measured with respect to a base year. Thus, even though able to trace variations with time of costs, they cannot capture the real differences in costs of living among countries.

In view of the scarcity of data on relative prices of hotels and restaurants, most researchers usually used the real effective exchange rate as a proxy, assuming that the prices of hotels and restaurants change in accordance with domestic currency. Hence, if the domestic exchange rate is not kept at a competitive level, potential tourists may switch their destination. In this study the following mathematical function is proposed to model the demand for Malaysian tourism:

$Q=f(Y, E R, Z)$

Where:

$\mathrm{Q}=$ Tourist demand in the destination country

$\mathrm{Y}=$ Income per capita of the origin country

$\mathrm{ER}=\mathrm{A}$ relative price index to measure price levels between the destination and origin the countries

$\mathrm{Z}$ = some other factors

Model specification: In demand model total room rented was used as dependent variable and explanatory variables are included: Real personal income per capita of destination countries, exchange rate as of index relative price between generation countries and Malaysia and finally Malaysian average daily hotel room price. Since we want keep the model size manageable, we are forced to choose only the principle determinants of tourism demand while leaving out influences that are deemed less central to behavior. In the supply model endogenous variable is average of hotel room rate and producer price index (production cost), room occupancy rate and total room rented and lag of average room rate had been used as an explanatory variables.

The sets of equations with supply and demand in log linear form are given below:

$$
\begin{aligned}
& \ln \mathrm{QRD}=\alpha_{10}+\alpha_{11} \ln \mathrm{Y}+\alpha_{12} \ln \mathrm{EX} \\
& +\alpha_{13} \ln \mathrm{ARR}+\ln \mathrm{QRD}(-1)+\mathrm{e}_{1} \\
& \ln \mathrm{ARR}=\alpha_{20+} \alpha_{21} \ln \mathrm{QRD}+\alpha_{22} \ln \mathrm{OCP} \\
& +\alpha_{23} \ln \mathrm{PPM}+\ln \mathrm{ARR}(-1)+\mathrm{e}_{2}
\end{aligned}
$$

Where:

$\mathrm{QRD}=$ Total room sold in Malaysia

$\mathrm{Y} \quad=$ Real personal income per capita generation countries

$\mathrm{EX}=$ Exchange rate

ARR = Malaysian average daily hotel room rate and $\mathrm{e}$ - is error term

OCP = The room occupancy rate, define as the ratio of quantity demand of rooms to room supply or room, capacity as it used before by Qu et al. (2002) in Hong Kong tourism model

$\mathrm{PPM}=$ Producer price index

$\mathrm{QRD}=$ Total room rented (or room sold)

-e- $\quad=$ Error term

In order for the estimate coefficients to be construed as elasticity's, the tourism supply and demand functions are estimated in log linear form too.

\section{MATERIALS AND METHODS}

We use a linear-log specification of the supply and demand models (Eq. 9 and 10). They are estimated by using the Weighted two-Stage LeastSquares estimator (W2SLS). All exogenous variables of the system are used as instruments for the endogenous variables. The parameter estimation of the model is showed in Table 1 . To detect the possibility of the presence autocorrelation in the disturbance term from the regression analysis, we have conducted a Durbin Watson $\mathrm{H}$ statistics test in all equations. 
Am. J. of Economics and Business Administration 3 (2): 410-415, 2011

Table 1: Results of the WTSLS estimation system equations

\begin{tabular}{|c|c|c|c|}
\hline \multicolumn{2}{|c|}{ Supply equation } & \multicolumn{2}{|c|}{ Demand equation } \\
\hline Variables & Coefficients & Variables & Coefficients \\
\hline $\mathrm{C}$ & $-9.55(-2.75)^{* * *}$ & $\mathrm{C}$ & $1.23(3.5)^{* * *}$ \\
\hline LCP & $1.47(2.48)^{* * *}$ & LY & $0.16(2.2)^{* *}$ \\
\hline LQ & $0.41(2.74)^{* * *}$ & LEX & 0.05 (1.11) \\
\hline LOCUP & $0.07(1.77)^{*}$ & LARR & $-0.22(-2.1)^{* *}$ \\
\hline LP(-1) & $0.54(2.93)^{* * *}$ & LQ(-1) & $0.88(16)^{* * *}$ \\
\hline DUM03 & $-0.01(-3.41)^{* * *}$ & DUM97 & $-0.04(-2.1)^{* *}$ \\
\hline $\mathrm{R}^{2} \mathrm{cn}=0.99$ & $\mathrm{DW}=2.09$ & $\mathrm{R}^{2} \mathrm{cn}=0.99$ & $\mathrm{DW}=2.08$ \\
\hline
\end{tabular}

Note: Significance levels denoted as follows ${ }^{* * *}$ : (1\%); **: (5\%) and *: (10\%), t- ratios in parentheses

Table 2: Short run and long run price elasticity's

\begin{tabular}{lll}
\hline Variables & Short run elasticity & Long run elasticity \\
\hline Price (Demand) & 0.22 & 1.83 \\
Price (Supply) & 2.30 & 5.30 \\
\hline
\end{tabular}

The obtained results indicate that there is no significant autocorrelation in the model. To determine the presence of heteroscedasticity we used the Breusch-Pagan test. Although, WTSLS and is a way to deal with the hetroskedasticity problem, the obtained results indicate that there is no significant hetroskedasticity in the model. Also, we apply Jarque-Bera test for normality testing. The result shows that the error terms for supply and demand equations have normal distribution.

\section{RESULTS AND DISCUSSION}

In the demand equation the coefficient of price variable (average hotel room rate) is -0.22 . This result clearly shows that tourists demand is price-inelastic in the short run and elastic in the long run. Elasticity of supply in the short run is equal to 2.3 and supply in the long run remains elastic (Table 1 and 2).

Also, the results of the demand model indicated that income significantly affects tourists demand in Malaysia. This result supports the economic theory that any change in consumer income tends to cause a change in demand for goods and services. In addition, our results complemented Habibi and Rahim (2009) and Norlida et al. (2007) findings that income is a significant determinant for tourism demand in Malaysia. Our results also show that the income elasticity is less than unity, indicating that tourism is not a luxury good in Malaysia. (As also found by Habibiadn Rahim (2009) and Norlida et al. (2007) for tourism in Malaysia). This result indicates the appreciation of exchange rate in Malaysia has less effect on Malaysian tourism demand although we know that the exchange rate was fixed during 2002-2006. The results show that Asian economic crises 1997-1998 and also 2003 SARC crises have negative effect on the Malaysian tourism flow. Despite the economic crises, tourist arrivals were increasing especially from western countries to Malaysia during these crises (Supported by Norlida et al., 2007).

Following a unit proportional change in price index with everything else constant brings a $1.47 \%$ positive change in average room rate. The result indicated that $1 \%$ increase in occupancy rate duo to increase in demand of room in short run has positive effect about $0.07 \%$ on average room rate. The average hotel occupancy rate during the sample period was 57.064. Statistics show that from year 2004 the occupancy rate has positive growth until 2007 despite the high growth rate of tourist arrivals the occupancy rate was $43 \%$ for 1995 , it only increased to $58 \%$ at 2009 . The main reason for this case is to commensurate growth in capacity in the lodging market.

The elasticity of supply is 2.43 therefore in this market, supply is elastic. A similar conclusion was obtained by Mak (1981); Bonham and Gangnes (1996) which finds no statistically significant impact of the room tax on room revenues. According to the authors since the tax is added to room bills on checkout it may not be visible to the tourist when planning a vacation. Also, these results are supported by Zhou et al. (2007) in the Hawaii tourism model. According to the authors the estimated elasticity for supply of hotel room is close to 2 . One of the main results of being supply elastic is that in the Malaysian hotel market there is excess supply. The statistics show that the hotel occupancy rate had a maximum 70\% during the 1995-2009. Another reason, the supplier can adjust the number of service workers. Therefore they are able to adjust number of workers in the short run base on Malaysian labor law to keep a certain offer price. These conditions can make supply elastic. Hence tourists in the long run are able to transfer $26 \%$ of the tax to suppliers meanwhile in the short and long run they transfer only $11 \%$ levy tax. Our results also indicate that a tax imposed on tourist spending has a negative output effects on the visitor industry. In this step we discussed about a certain percent imposed tax (5\%) on tourism price. After the calculation value of $\mathrm{Q}^{*}$ and $\mathrm{P}^{*}$ 
for every quarter from 1995Q1 until 2009Q4 we obtained a value of total revenue before and after tax and total government revenue. The results indicate that in the short run the total revenue in the private sector plus total tax is bigger than the difference of total revenue before and after tax.

\section{CONCLUSION}

Based the results if the government imposes one ringgit (Malaysian currency) tax on hotel room price, the tourist contribution is more than 89 and $74 \%$ in the short run and long run respectively. Hence, we conclude that the Malaysian tourism market is exportable. The social cost of tax is negative because we don't have any losses from the tax. Also, the results indicate that if the government imposes a tax on tourism price, tourism expenditure increased because demand is inelastic and supply is very elastic in the short run. But in the long run demand is elastic and therefore these results are not obtainable. In the long run the total revenue in private sector plus the total tax is bigger than the difference of total revenue before and after tax. In this case the social cost of tax is positive. Based on these results if the government imposed a tax on tourism price, tourism expenditure decreased due to demand $(\mathrm{Ed}=1.83)$ is elastic in the long run.

\section{REFERENCES}

Anastassiou, T. and C. Dritsaki, 2005. Tax revenues and economic growth: An empirical investigation for Greece using causality analysis. J. Soc. Sci., 1: 99-104. DOI: 10.3844/jssp.2005.99.104

Arbel, A. and S.A. Ravid, 1983. An industry energy price impact model: The case of the hotel industry. Applied $\quad$ Econ., 15: 705-714. http://ideas.repec.org/a/taf/applec/v15y1983i6p705 $-14 . h t m l$

Berno, T., 2001. Sustainable tourism development: the long road from theory to practice. Int. J. Econ. Dev. 3: 1-8. http://www.spaef.com/file.php?id=1061

Bonham, C. and B. Gangnes, 1996. Intervention analysis with cointegrated time series: The case of the Hawaii hotel room tax. Applied Econ. J., 28: 1281-1293. DOI: 10.1080/000368496327831
Crouch, G., 1994. The study of international tourism demand: A survey of practice. J. Travel Res., 32: 41-55. DOI: $10.1177 / 004728759403200408$

Fosu, O.E. and F.J. Magnus, 2008. Aggregate import demand and expenditure components in Ghana. J. Soc. Sci., 4: 1-6. DOI: 10.3844/jssp.2008.1.6

Fujii, E.T. and J. Mak, 1981. Forecasting tourism demand: Some methodological issues. Annals Regional Sci., 15: 72-82. DOI: 10.1007/BF01287440

Habibi, F. and K.A. Rahim, 2009. A bound test approach to co integration of tourism demand. Am. J. Econ. Bus. Admin., 1: 165-172. DOI: 10.3844/.2009.1924.1931

Hiemstra, S.J. and J.A. Ismail, 1993. Analysis of room taxes levied on the lodging industry. J. Travel Res., 31: 42-49. DOI: 10.1177/004728759203100109

Mak, J., 1988. Taxing hotel room rentals in the US. J. Travel Res., 27: 10-15. DOI: 10.1177/004728758802700103

Mohebi, M. and A.R. Khalid, 2010. Revenue determinants in tourism market. Am. J. Applied Sci., 7: 1593-1598. DOI: 10.3844/ajassp.2010

Norlida, H., M. Salleh and O. Redzuan and R. Sridar, 2007. Malaysia's tourism demand from selectedcountries: The ARDL approach to cointegration. Int. J. Econ. Manage., 1: 345-363. ISSN: 1823-836X

Qu, H., P. Xu and A. Tan, 2002. A simultaneous equations model of the hotel room supply and demand in Hong Kong. Hospitality Manage., 21: 455-462. DOI: 10.1016/S0278-4319(02)00031-2

Seifolddini-Faranak, M.S. Fard and H. Ali, 2009. Distribution and determining of tourist attractions and modeling of tourist cities for the city of Isfahan-Iran. Am. J. Econ. Bus. Admin., 1: 160166._DOI: 10.3844/ajebasp.2009.160.166

Smith, S.L.J., 1988. Defining tourism: A supply-side view. Annals Tourism Res., 15: 179-190. DOI: 10.1016/0160-7383(88)90081-3

Zhou, T., C. Bonham and B. Gangnes, 2007. Modeling the supply and demand for tourism: A fully identified VECM approach. University of Hawaii Economic Research Working Paper. http://EconPapers.repec.org/RePEc:hai:wpaper:200 717 